\title{
Phenotypic plasticity in habitat use and growth of the European eel (Anguilla anguilla) in transitional waters in the Mediterranean area
}

\author{
Fabrizio Capoccioni ${ }^{1}$, Dai-Yu Lin ${ }^{2}$, Yoshiyuki lizuka ${ }^{3}$, Wann-Nian Tzeng ${ }^{2,4}$, Eleonora Ciccotti ${ }^{1}$ \\ ${ }^{1}$ Dipartimento di Biologia, Università Roma Tor Vergata, Roma, Italy \\ ${ }^{2}$ Institute of Fisheries Science, National Taiwan University, Taipei, Taiwan \\ ${ }^{3}$ Institute of Earth Sciences, Academia Sinica, Taipei, Taiwan \\ ${ }^{4}$ Department of Environmental Biology and Fisheries Science, National Taiwan Ocean University, Keelung, Taiwan
}

Accepted for publication March 7, 2013

Abstract - Lagoons and estuaries are transitional waters (TW), saline in character but substantially influenced by freshwater (FW) flows and the most productive habitat after upwelling areas. The European eel, Anguilla anguilla, is a typical inhabitant of these habitats and a target of important lagoon fisheries since ancient times.

Notwithstanding this, in the Mediterranean region, where the numerous coastal lagoons are the most eligible habitat for this species, eel habitat use and growth, which display a high inter-individual variability, are poorly studied. To gain knowledge about the migratory behaviour and the relative growth history of this species in TW in the Mediterranean area, the otolith $\mathrm{Sr} / \mathrm{Ca}$ ratios of 56 individuals were analysed. The study sampling sites were two typical coastal lagoon environments, Caprolace lagoon and Lesina lagoon, located, respectively on the Tyrrhenian and the Adriatic coast of Italy, and the Tiber River (TR) estuary, in Central Italy. Otolith $\mathrm{Sr} / \mathrm{Ca}$ profiles revealed that in all the sites, the resident contingent is substantial, while the proportion of nomad eels, or habitat inter-shifter, was different among sites. Mean annual grow rate of resident eels is higher in productive environments (TR and lagoon of Lesina), while in Caprolace lagoon, an oligotrophic lagoon, resident eels grow slower. The observed patterns of habitat use and growth seem linked to local ecological conditions: facultative movements of eels with a nomadic behaviour seem affected by food availability rather than by the salinity gradient. This consideration supports the hypothesis that the facultative catadromous migration of European eel in Mediterranean TW, and the trophic shifts that this species exhibits, depend primarily on the productivity of the environment rather than on its salinity gradient.

Key words: Sr:Ca ratio; Anguilla anguilla; transitional waters; growth; habitat use; Mediterranean region

\section{Introduction}

Coastal lagoons are coastal water bodies characterised by being shallow and separated by coastal barriers from the adjacent sea, but still in communication with it by means of tidal channels. These ecosystems are thus characterised by the presence of boundaries and transitions between land and water, between lagoon and sea and, frequently, between the waters in the lagoon and FW inputs. Each boundary involves strong physical and ecological gradients that make them dynamic systems.
Because of these characteristics, coastal lagoons, and transitional waters (TW) generally, are among the aquatic habitats showing the highest biological productivity (Carrada \& Fresi 1988; Alonghi 1998; Tett et al. 2003). They play an important ecological role in coastal ecosystems by providing an assortment of habitat types for many species. They function as essential habitats for many organisms, providing important nursery grounds for juveniles of many marine, estuarine and FW fishes, conduits for species that move between the sea and rivers, and feeding and staging sites for significant populations of migratory 


\section{Capoccioni et al.}

species (Franco et al. 2006). These environments hence also house a high biodiversity. More than 621 species of macrophytes and 199 species of fishes are present in coastal lagoons in the Atlanto-Mediterranean region (Pérez-Ruzafa et al. 2011). The fact that coastal lagoons provide a refuge for many species, and function as nursery areas and feeding grounds for marine species suggests that these organisms have developed physiological adaptations to survive in these changing environments. Such adaptations involve a high energetic cost that is reflected in growth and reproduction rates.

Lagoons have historically been of great interest to humans exactly because they offer high biological productivity. Fisheries represent a highly intensive exploitation of coastal lagoons resources. They target a number of commercial fish from the Sparidae, Mugilidae, Anguillidae and Moronidae families (Kapetsky \& Lasserre 1984), which are present in more than the $75 \%$ of Mediterranean lagoons (PérezRuzafa et al. 2007, 2011). Fish communities of TWs have peculiar features displaying high abundances of few r-strategist species, with wide ecological amplitude, generally low diversity and high biological productivity (Odum 1969, 1985). In numerous lagoons, fish production has been found to be significantly correlated with fluvial inputs, due to the high load of both nutrients and detritus carried downstream, which stimulate planktonic food webs (Hilmer \& Bate 1991; Whitfield \& Wooldridge 1994; Franco et al. 2006). In addition, the organic substance-rich sediments that are found near FW inputs sustain a rich benthic community that constitutes the feeding ground for many benthophagous fishes including Anguilla anguilla.

This species is exploited by fisheries across its distribution area, in continental waters such as rivers, lakes and coastal lagoons. For more than 10 years, the general picture on the status of eel stocks and fisheries has exhibited declining recruitment and reduced yields, apparent both from capture fisheries and from scientific indices throughout Europe (ICES 2006).

In recent years, the Anguillid eel has been demonstrated to be a facultative catadromous species, because part of its population has no FW experience (Daverat et al. 2006; Tabouret et al. 2010). This observation relies on the description of migratory patterns of the eel in its growth phase on the basis of otolith microchemistry analysis, that allows discrimination between fresh, brackish and sea water contingents in many aquatic habitats at different latitudes (Tzeng et al. 1997, 2000; Tsukamoto et al. 1998; Shiao et al. 2006). The otolith strontium/calcium ( $\mathrm{Sr}: \mathrm{Ca})$ ratio is widely used to describe eel habitat shifts in TW because this is a chemical tag widely accepted to describe fish movements across different environments (Campana 1999; Elsdon et al. 2008).
The positive and predictable relationship that has been established by numerous experimental studies (Thorrold et al. 1997; Kraus \& Secor 2004; Zimmerman 2005) between salinity, temperature and element concentration of ambient water and molar ratio of $\mathrm{Sr}$ to $\mathrm{Ca}$ in the fish otoliths, also confirmed by field studies, is the fundamental assumption that makes the otolith Sr:Ca ratio such a powerful tool to distinguish the migratory life histories of fishes moving between FW and saltwater habitats (Campana 1999; Elsdon \& Gillanders 2002; Elsdon et al. 2008). In fish that traverse estuarine salinity gradients during their life history, such as diadromous fishes, measurements of the $\mathrm{Sr}: \mathrm{Ca}$ ratios in otoliths have been widely used to infer life-history periods spent in fresh, brackish and marine environments (Brown \& Severin 2009). This approach has also been found to be reliable for the European eel (Tzeng et al. 2000; Arai et al. 2006; Daverat \& Tomás 2006; Shiao et al. 2006; Lin et al. 2009) because $\mathrm{Sr}: \mathrm{Ca}$ ratios in their otoliths are strongly correlated with the salinity of the water and its chemistry but is little affected by other factors such as water temperature, food and physiological factors (Kawakami et al. 1998). In marine species, on the other hand, factors influencing otolith $\mathrm{Sr}: \mathrm{Ca}$ variations are more likely to be physiological in nature (Campana 1999; Secor \& Rooker 2000) because water chemistry has a more homogeneous $\mathrm{Sr}$ :Ca ratio in the marine environment, as recently pointed out by Brown \& Severin (2009).

The general pattern of habitat use described for the eel accounts for a preferential residence in brackish and marine habitats at higher latitudes, as shown by the higher proportion of individuals in the salt water (i.e., brackish and sea waters) contingents, (Daverat et al. 2006). In contrast, eels at low latitudes are believed to inhabit preferentially FW (Daverat et al. 2006). This phenomenon is attributed to the latitudinal difference in the aquatic productivity between FW and seawater (SW), that is, productivity at the lower latitudes is higher in FW than in salt water, contrary to the higher latitudes where productivity is higher in salt water than in FW (Gross 1987). Nevertheless, this observation does not take into account the fact that TW in the Mediterranean, and coastal lagoons in particular, are notably the most productive habitats, with respect to both SW and FW (Acou et al. 2003).

Wherever they occur, eel inter-habitat shifts are short range (approximately $10 \mathrm{~km}$ ) when compared with the migrations of silver eels and leptocephalus larvae, but, nevertheless, they are of considerable importance because they occur during the prolonged growth (yellow eel) stage and involve switching between environments that are completely different in terms of salinity, temperature, substrate, depth, as well as a large number of other environmental conditions 
(Thibault et al. 2007). As a consequence of these considerations, the mechanism of facultative behaviour for eels at different latitudes is still controversial, and cannot be directly predicted by the environmental conditions (e.g., aquatic productivity) alone.

This aspect requires more sampling and analyses of eel local stocks from southern regions, and this work aims at filling this gap. The aims of this study were to assess the migratory pattern of the European eel in TW at lower latitudes and to validate growth differences among eels with different strategies of habitat use. The wider purpose of the work is to add insight into the understanding of the factors affecting the habitat use by eels in lagoons to ascertain the role and the relevance of Mediterranean coastal lagoon environments as growing habitats for the European eel.

\section{Materials and methods}

\section{Environmental characteristics of sampling sites}

Sampling has been carried out at three Mediterranean locations (Fig. 1), two coastal lagoons and the low course of a river, characterised by different environmental features and different ranges of salinity.

The Tiber River (TR) basin drains an area of about $17,000 \mathrm{~km}^{2}$ in central Italy and, with a length of $409 \mathrm{~km}$, flows through the Tuscany, Umbria and Lazio regions. It runs through the city of Rome (2.7 million residents) with a plain estuary that divides in two branches before flowing into the Tyrrhenian Sea (annual mean flow is $232 \mathrm{~m}^{3} \cdot \mathrm{s}^{-1}$; Patrolecco et al. 2010). The salinity front in the estuary extends about $7 \mathrm{~km}$ upstream from the river mouth, although its amplitude depends on tide and river discharge. The sampling area is the lower river course, downstream of the city of Rome, situated $20 \mathrm{~km}$ from the mouth. This stretch can be considered a FW habitat because salinity is $0 \mathrm{psu}$ in all seasons. During the year, the mean water temperature is $17.2^{\circ} \mathrm{C}\left(\min 10^{\circ} \mathrm{C}, \max 23.7^{\circ} \mathrm{C}\right)$. Annual mean precipitation is about $737.7 \mathrm{~mm}$, with 74.6 rainy days (Istituto Idrografico 2010).

The brackish coastal lagoon of Lesina (LL), located on the southern Adriatic coast of Italy (Fig. 1), covers a surface area of $51.4 \mathrm{~km}^{2}$, mean water depth is $1 \mathrm{~m}$. LL displays a mean salinity of $15.8 \mathrm{psu}(\max 28.4 \mathrm{psu}$

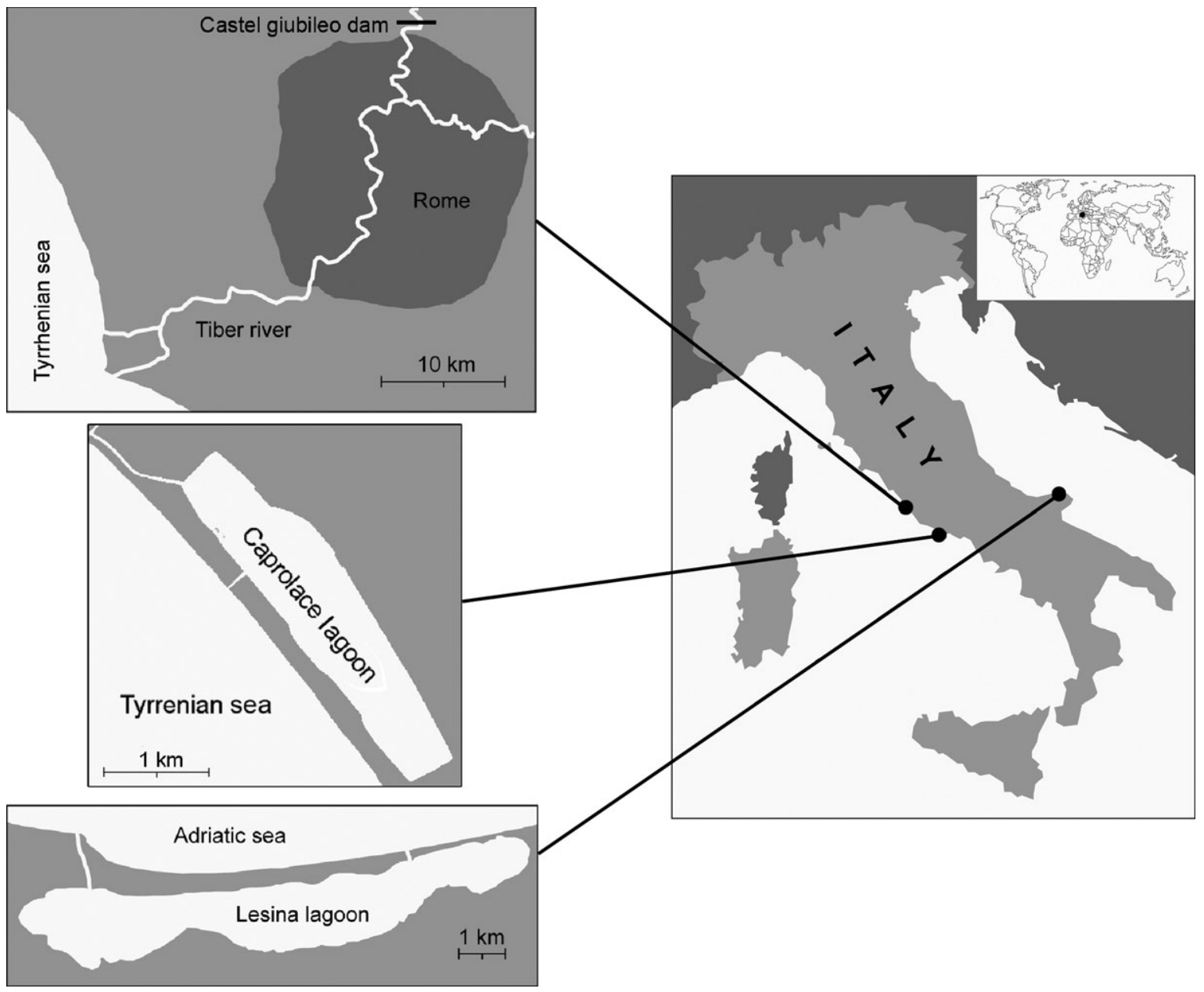

Fig. 1. Location of the three study sites (lower Tiber River, Lesina lagoon and Caprolace lagoon). 


\section{Capoccioni et al.}

and min $10.3 \mathrm{psu}$ ). Lesina lagoon is connected to the sea through two inlets and has several FW inputs, such as two perennial tributaries and several domestic and agricultural canals (Nonnis Marzano et al. 2003). Seasonal salinity fluctuations are not severe due to the FW inputs that mitigate the effect of evaporation in summer months. On the other hand, an east-west spatial salinity gradient exists all over the year between different areas of the lagoon due to the reduced water circulation and the considerable contribution of FW inputs concentrated on the south-eastern side of the lagoon (Manzo 2010). Water temperature ranges from 10.3 to $27.6{ }^{\circ} \mathrm{C}$ (mean value: $18.4{ }^{\circ} \mathrm{C}$; Roselli et al. 2009). Annual mean rainfall is about $635 \mathrm{~mm}$ (http:// www.meteoam.it).

Caprolace lagoon (CL), within the Circeo National Park (Latina, Latium), is part of the coastal Pontine lagoons system, Central Italy (Fig. 1). Its surface area is $2.26 \mathrm{~km}^{2}$ with an average depth of $1.3 \mathrm{~m}$ (maximum $2.9 \mathrm{~m}$ ). Water exchange with the sea is by two inlets. In order to reduce pollutant load, FW inputs draining the surrounding cultivated land were diverted in the late 1970s (Prato et al. 2009). As a consequence, salinity has increased in the last two decades, up to the present with a mean of 38.1 psu (min 34.6 psu, max $41.4 \mathrm{psu}$ ). Annual salinity fluctuations are a direct consequence of air temperature and rainfall (about $688.9 \mathrm{~mm}$ per year, with 76.6 of rainy days; Istituto Idrografico di Roma 2010). Both factors, in addition to the shallow depth of the lagoon, influence salinity that decreases in the winter months due to the rains, and exceeds sea values in summer due to evaporation and to the strong thermal winds also characteristic of this season. Annual average water temperature is $18.5^{\circ} \mathrm{C}\left(\min 8.7^{\circ} \mathrm{C}, \max 29.1^{\circ} \mathrm{C}\right)$.

\section{Fish collection}

A total of 180 eels were collected, 60 from each sampling site, using fyke nets, during 2007/2008.

All individuals were measured for total length $(L, \mathrm{~cm})$ and weight $(W, \mathrm{~g})$. Sex was assessed macroscopically whenever possible, otherwise by histological examination of gonad tissue following the guidelines of Colombo \& Grandi (1996).

\section{Age reading}

The two largest otoliths (sagittae) were extracted from all adults, oven-dried and stored. The left sagitta was embedded in epoxy resin then ground on the convex side (grinding and polishing method; ICES 2009) and then stained with $3 \%$ toluidine blue. Conventionally (ICES 2009), age for eel is evaluated by counting from the first ring after the central core of the otolith that accounts for the marine larval and postlarval period of the eel. Assigned age corresponds, therefore, to the years of the animal starting from its colonisation of the continental water body.

\section{Microchemistry analysis of the otolith}

The Sr:Ca ratios of the right polished otoliths from 56 individuals $(15,20$ and 21, respectively, from TR, LL and CL) were measured by a JEOL JXA-8900R (Tokyo, Japan) Electron Probe Micro Analyzer (EPMA), from the primordium to the edge, with an interval of $10 \mu \mathrm{m}$, as detailed in Lin et al. (2009). The reliability of this technique to assess the habitat use of A. anguilla in peculiar ecological conditions has been recently validated (Panfili et al. 2012). The time resolution of EPMA was approximately 1-2 points per month in the otolith.

The migratory pattern of the eel was classified into FW type, SW type (SW), brackish water type (BW) as well as inter-habitat shifter type (HIS), based on the correlation between $\mathrm{Sr}: \mathrm{Ca}$ ratio registered at the otolith edge (corresponding to the last month of growth) and the water salinity values measured during the month before the eel capture. Moreover, 25 otoliths were randomly selected and additionally analysed along the edge for approximately 20 points from the three study sites (i.e., five from TR, 11 from LL and nine from CL) to understand the variability of Sr:Ca ratios in otolith of the eel and the accuracy and precision of the Sr:Ca measurements. The criterion of $\mathrm{FW}$ was defined from mean $\mathrm{Sr}$ :Ca ratios at the edge of nine eel otoliths from TR (range $=1.9$ $3.9 ;$ mean $\pm \mathrm{SD}=2.8 \pm 0.8 \times 10^{-3}$ ), while the criterion of SW was defined from mean $\mathrm{Sr}: \mathrm{Ca}$ ratios of 21 otoliths from CL eels (range = 7.5-13.5; mean $\left.\pm \mathrm{SD}=10.3 \pm 1.7 \times 10^{-3}\right)$. The two criteria were used to test the annual change in $\mathrm{Sr}: \mathrm{Ca}$ ratio of each otolith from the zero band (i.e., elver check) to the edge. The classification of migratory patterns was tested using the one-tailed unpaired $t$-test under 95\% confidence level. The test hypotheses are as follows:

1. The Sr:Ca ratio measured in each point along the otolith transect is continually significantly higher than the FW criterion.

2. The Sr:Ca ratio measured in each point along the otolith transect is continually significantly lower than the SW criterion.

If the test results reject the hypothesis (1) but accept (2), the eel is classified as FW resident $\left(R_{\mathrm{FW}}\right)$. If the test results reject the hypothesis (2) but accept (1), the eel is classified as saline water resident $\left(R_{\mathrm{SW}}\right)$. If the test results accept the two hypotheses, the eel is classified as $\mathrm{BW}$ resident $\left(R_{\mathrm{BW}}\right)$, while if the test reject both hypotheses, the eel is classified as habitat inter-shifter (HIS). Only the ratios, calculated 
along the otolith transect, from a distance $>200 \mu \mathrm{m}$, (generally corresponding to the start of the continental growth) were used to compute the classification.

\section{Back-calculation of fish length-at-age}

Individual growth in length was reconstructed by back-calculation through otolith reading for 56 specimens, as successfully done in A. anguilla (Lin et al. 2007; Pujolar et al. 2009b) and other eel species (Jessop et al. 2004). Size-at-age was back-calculated according to the 'body-proportional hypothesis' (Francis 1990). For each site, maximal otolith radius was regressed from core to edge $(R)$ on total body length $(L)$ after log-transformation of both variables:

$\log L=\alpha+\beta \log R$

Then, the scaling coefficient $b$ of the $L-R$ relationships $(b=1.02,1.01$ and 0.95 in TR, CL and Lesina lagoon, respectively) was used to compute the backcalculated body length $L_{i}$ at age $i$, namely:

$$
L_{i}=\left(R_{i} / R\right)^{\beta} L
$$

where $R_{i}$ is the otolith radius at annulus $i$.

\section{Results}

\section{Comparison of biological information among habitats}

Table 1 compares the biological information and the growth rates among samples: eels are older in CL $(8 \pm 2.4$ years old $)$, followed by TR $(5.4 \pm 2.5$ years old) and youngest in LL $(4.6 \pm 1.8$ years old; ANOVA, $P<0.05)$. The mean $( \pm \mathrm{SD})$ growth rate was highest in LL $\left(8.5 \pm 2.9 \mathrm{~cm} \cdot\right.$ year $\left.^{-1}\right)$, followed by TR $\left(5.1 \pm 1.7 \mathrm{~cm} \cdot\right.$ year $\left.^{-1}\right)$ and CL $\left(4.4 \pm 1.0 \mathrm{~cm} \cdot\right.$ year $^{-1}$; ANOVA; all pairwise comparisons, $P<0.05$ ). This indicates that eels in LL are youngest and grow fastest, followed by eels in TR, eels in CL are oldest and grow slowest. The correlation coefficient $(r)$ between mean annual growth rate and age also indicates that growth rate decreases with increasing age, irrespective of sex or habitat (ANOVA, $P<0.01$ ). The mean annual growth rate was statistically compared among sites and sexes by two-way ANOvA. The results reveal that the growth rate was significantly different among the three sites (two-way anova, $P=0.000$ ) and between male and female eels (two-way ANova, $P=0.014$ ). However, no significant correlation between site and sex was found in the eels' growth rate (two-way ANOvA, $P>0.05$ ).

Relationship between otolith Sr:Ca ratio and habitat salinity

A positive and significant relationship between $\mathrm{Sr}: \mathrm{Ca}$ ratio measured at the edge of the otolith and the correspondent salinity values $(S)$ recorded in the last month in the three different habitats is showed in Fig. $2 \quad\left(\mathrm{Sr}: \mathrm{Ca}\right.$ ratio $=0.17 \times S+4.35 ; R^{2}=0.63$; ANOva, $P<0.01)$. In addition, to test the accuracy and precision of the otolith $\mathrm{Sr}: \mathrm{Ca}$ analysis, 20 measurements of $\mathrm{Sr}: \mathrm{Ca}$ ratio were made along the otolith edge of 25 eels, randomly selected from the whole sample (i.e., five from TR, 11 from LL and nine from $\mathrm{CL}$ ), and salinity $(S)$. Also in this case, a simple linear regression was fitted showing a positive and significant correlation between these parameters $\left(\mathrm{Sr}: \mathrm{Ca}\right.$ ratio $=0.18 \times S+4.77 ; R^{2}=0.49 ;$ ANOVA, $P<0.01)$. Comparing these two linear regressions of the otolith Sr:Ca ratio with salinity, no significant differences were found (ANCOVA, $P=0.15$ ) revealing that $\mathrm{Sr}: \mathrm{Ca}$ analysis is reliable, irrespective of the different measuring sites in the otolith.

Patterns of habitat use of the eel as indicated by its otolith Sr:Ca ratios

In TR, $60 \%$ of the otoliths accounted for a $R_{\mathrm{FW}}$ strategy (FW resident, otoliths with $\mathrm{Sr}: \mathrm{Ca}$ ratio values continually below $2.8 \pm 0.8 \times 10^{-3}$ ), while the

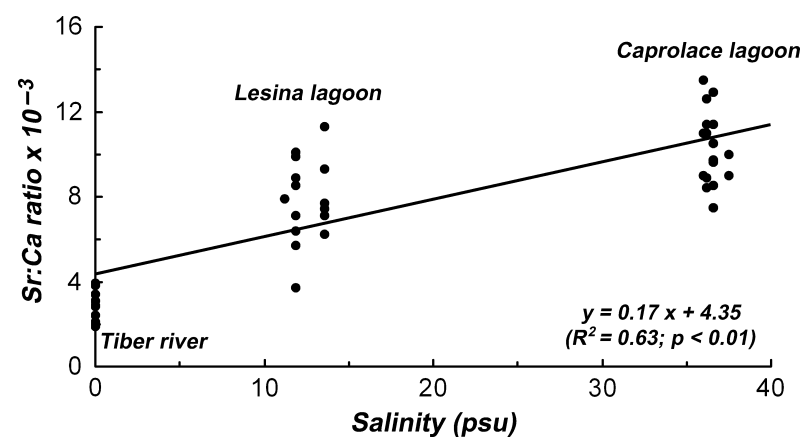

Fig. 2. The correlation of $\mathrm{Sr} \mathrm{Ca}$ ratio with salinity in the last month for the eels collected from the three different habitat: Tiber River, Lesina lagoon and Caprolace lagoon.

Table 1. Biological data of eels sampled in the three study sites.

\begin{tabular}{|c|c|c|c|c|c|c|}
\hline \multirow[b]{2}{*}{ Location } & \multirow[b]{2}{*}{ Samples $(M)$} & \multirow{2}{*}{$\begin{array}{l}\text { Sex ratio } \\
\text { (F:M:Und) }\end{array}$} & \multicolumn{4}{|l|}{ Mean \pm SD (range) } \\
\hline & & & Length $(\mathrm{cm})$ & Weight (g) & Age (year) & Growth rate $\left(\mathrm{cm} \cdot \mathrm{year}^{-1}\right)$ \\
\hline Tiber River & 60 & $6: 21: 33$ & $34.1 \pm 11.6(20.0-81.0)$ & $99.5 \pm 146.1(12.6-960.0)$ & $5.4 \pm 2.5(2-15)$ & $5.1 \pm 1.7(1.9-10.8)$ \\
\hline Lesina lagoon & 60 & $50: 0: 8$ & $43.2 \pm 11.1(27.0-71.0)$ & $164.2 \pm 149.9(25.5-693.0)$ & $4.6 \pm 1.8(1-12)$ & $8.5 \pm 2.9(4.7-22.9)$ \\
\hline Caprolace lagoon & 60 & $35: 9: 16$ & $41.0 \pm 10.2(27.0-72.0)$ & $121.7 \pm 111.8(23.2-655.3)$ & $8.0 \pm 2.4(4-16)$ & $4.4 \pm 1.0(2.9-7.8)$ \\
\hline
\end{tabular}




\section{Capoccioni et al.}

other $40 \%$ were classified as HIS. In LL, Sr:Ca ratios from the elver check to the otolith edge of 13 eels $(65 \%)$ accounted for a continue residence in BW $\left(R_{\mathrm{BW}}\right)$, since the elver stage, whereas $35 \%$ account for the HIS strategy, because fluctuating between the ranges of brackish and SW criteria. In CL, all samples have been classified as HIS, because no otoliths showed an Sr:Ca pattern continually over or under the saline water and FW criterion, respectively.

Eight profile patterns were found in the three sampling sites, TR, LL and CL and they were shown respectively in the Fig. 3, 4 and 5. Two patterns (Figs 3a and 4a) account for a typology of resident eels, either in FW, BW or saline water, and six of the observed patterns account for a typology of HIS eels (Figs 3b,c, 4b,c and 5a,b).

Among TR shifter eels, most (60\%) lingered in FW for more than a year after metamorphosis after first entry in continental waters, but moved between FW and $\mathrm{BW}$ habitats in the following period ( $\left.\mathrm{HIS}_{\mathrm{FW}-\mathrm{BW}}\right)$.
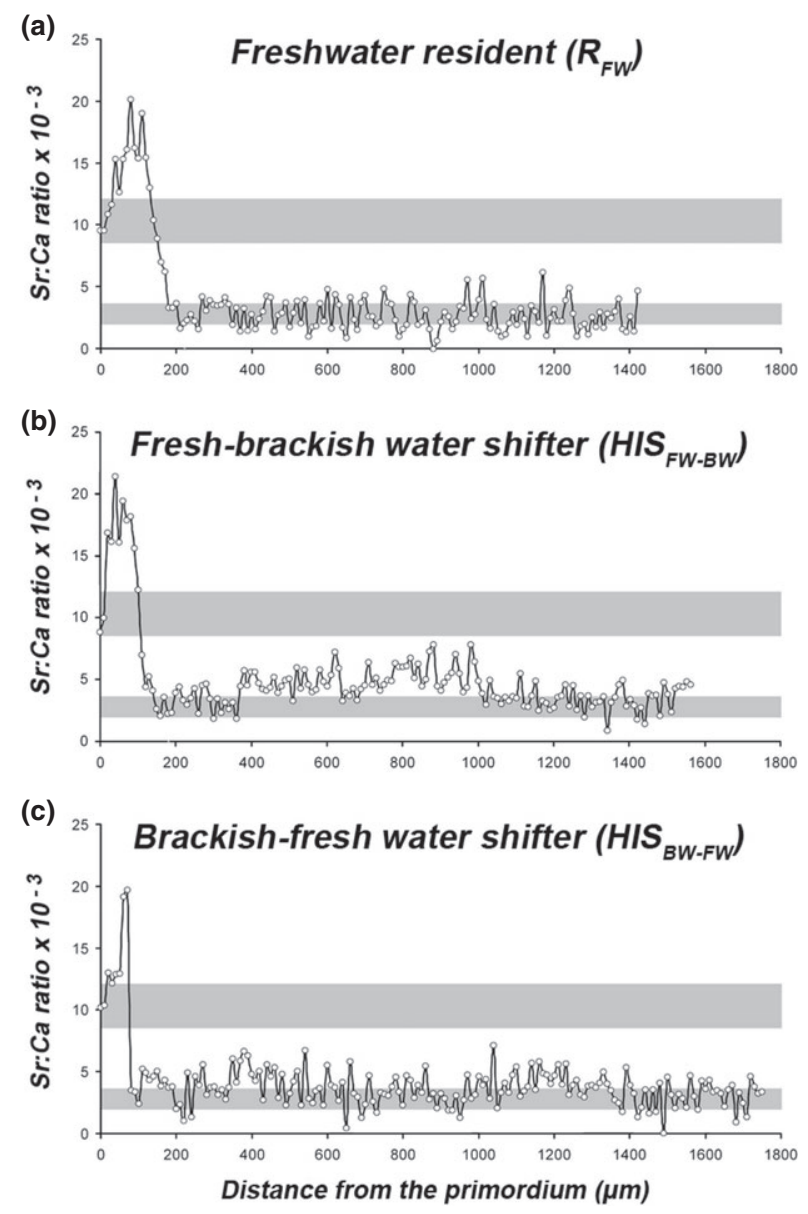

Fig. 3. Examples of $\mathrm{Sr}$ Ca ratios profiles along the otolith radius from the primordium to the edge, representative of the different migratory pattern typologies shown by eels from the estuary of the Tiber River: freshwater $(\mathrm{FW})$ resident eels $\left(R_{\mathrm{FW}}\right.$, a) and habitat inter-shifter eels $\left(\mathrm{HIS}_{\mathrm{FW}-\mathrm{BW}}, \mathrm{b}\right.$, and $\left.\mathrm{HIS}_{\mathrm{BW}-\mathrm{FW}}, \mathrm{c}\right)$. Grey bars represent the criteria of FW $\left(2.8 \pm 0.8 \times 10^{-3}\right)$ and seawater $\left(10.3 \pm 1.7 \times 10^{-3}\right)$.
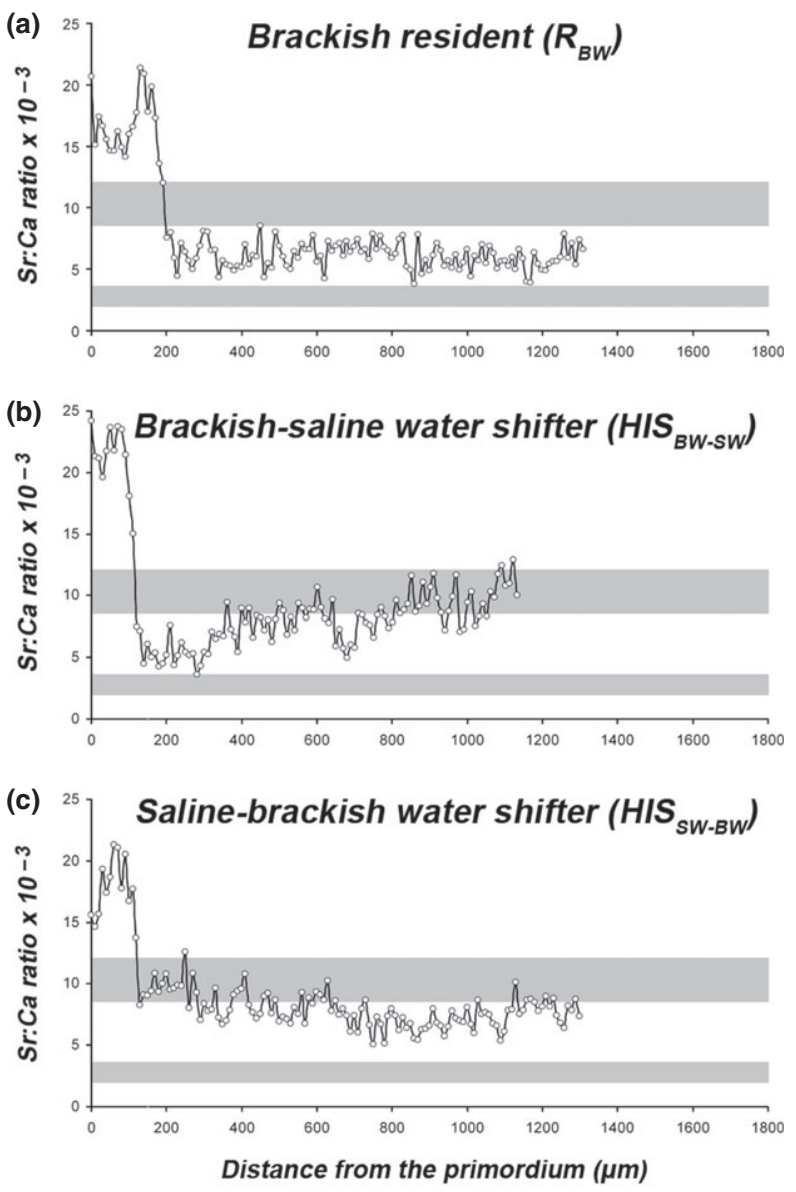

Fig. 4. Examples of $\mathrm{Sr}$ Ca ratios profiles along the otolith radius from the primordium to the edge, representative of the different migratory pattern typologies shown by eels from the Lesina lagoon: brackish water resident eels $\left(R_{\mathrm{BW}}\right.$, a) and habitat intershifter eels ( $\mathrm{HIS}_{\mathrm{BW}-\mathrm{SW}}, \mathrm{b}$, and $\left.\mathrm{HIS}_{\mathrm{SW}-\mathrm{BW}}, \mathrm{c}\right)$. Grey bars represent the criteria of freshwater $\left(2.8 \pm 0.8 \times 10^{-3}\right)$ and seawater $\left(10.3 \pm 1.7 \times 10^{-3}\right)$.

An opposite behaviour was displayed by the remaining $40 \%$ of TR shifter eels, which remained in BW habitat during the first period and then showed habitat shifts between BW and FW (HIS $\mathrm{BW}_{\mathrm{BWW}}$ ).

In LL, $65 \%$ of eels resided in BW and did not move to FW or SW during the period between the elver stage and sampling. Among the remaining $35 \%$, some eels settled in BW for some years (1-4) before moving to SW up until sampling ( $\mathrm{HIS}_{\mathrm{BW}-\mathrm{SW}}$ ), while a second group settled for the first few years in SW and then showed habitat shifts between BW and SW (HIS SW-BW $_{\text {). }}$

In $\mathrm{CL}$, at a first examination, the resident behaviour was never observed, because most eels $(85.7 \%)$ yielded a Sr:Ca pattern accounting for shifts between brackish and SW for periods shorter than 1 year, that is, corresponding to a time resolution of EPMA of $<6$ points, and were hence classified as frequent shifters (HIS type). At a closer inspection, however, the Sr:Ca pattern observed in most $(>85 \%)$ of these eels 

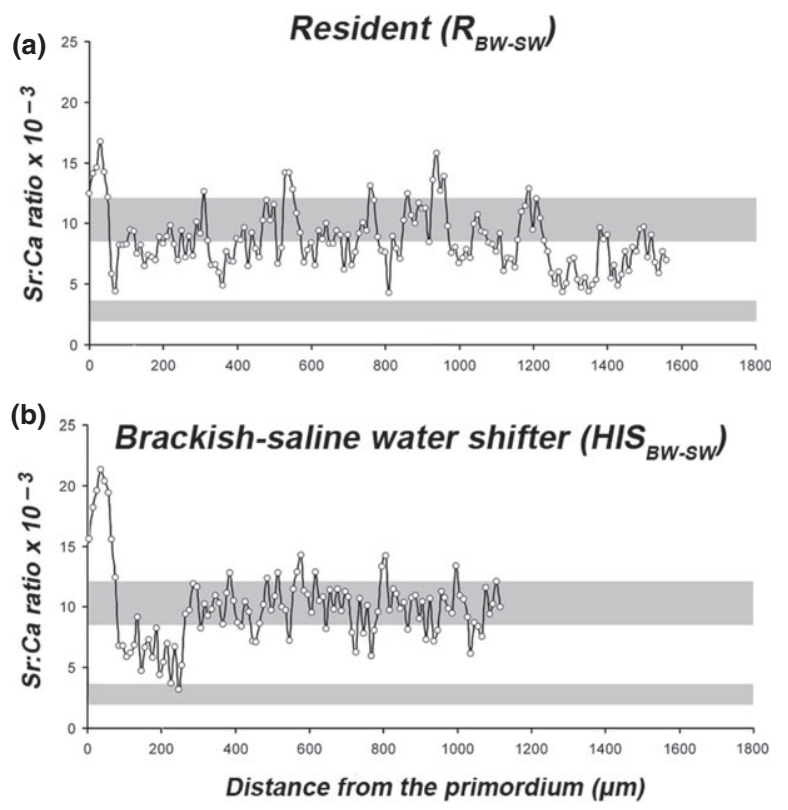

Fig. 5. Examples of $\mathrm{Sr}: \mathrm{Ca}$ ratios profiles along the otolith radius from the primordium to the edge, representative of the different migratory pattern typologies shown by eels from the Caprolace lagoon: resident eels $\left(R_{\mathrm{BW}-\mathrm{SW}}, \mathrm{a}\right)$ and habitat inter-shifter eels

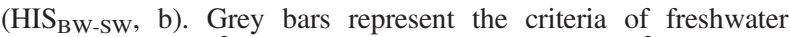
$\left(2.8 \pm 0.8 \times 10^{-3}\right)$ and seawater $\left(10.3 \pm 1.7 \times 10^{-3}\right)$.

is more probably due to the salinity pattern displayed by CL. The hydrological situation of this small marinised lagoon is such that a salinity pattern on a seasonal basis can be observed, due to meteorological events, lowering in winter because of rainfall and increasing in summer because of evaporation. As Elsdon et al. (2008) point out, an important but overlooked scenario, when interpreting otolith chemical tags, is that a change in the otolith chemistry could reflect a change in the environment surrounding a stationary fish. Such could be the case of this contingent, which therefore might be more correctly defined as a $R_{\mathrm{BW}-\mathrm{Sw}}$ contingent.

The Sr:Ca ratio of three eels $(14.3 \%)$ of the CL sample showed values in the BW range for the few first years, then moving over the SW threshold (HIS $\left.\mathrm{HW}_{\mathrm{BW}-\mathrm{FW}}\right)$. In addition, all $\mathrm{Sr}: \mathrm{Ca}$ ratios of eels grown in $\mathrm{CL}$ were higher than the FW threshold, and this accounts for the fact that these eels never ventured in FW habitats.

\section{Back-calculated fish length-at-age}

The linear regression was fitted to logarithmically (base 10) transformed total length (Log LT) against logarithmically (base 10) transformed otolith radius (Log OT) by the back-calculation equation of scale proportional hypothesis (SPH; Francis 1990; Francis 1995) for eels among the three sites. Results indicate that otolith radius-at-length for LL eels (the slope of regression $=0.95$ ) was significantly smaller than radius of eels either from TR (the slope of regression $=1.02$ ) and CL eels (the slope of regression $=1.01 ;$ ANCOVA; LL vs. TR or LL vs. CL, $P=0.000)$. No significant differences were observed between TR and CL otolith radius (ANCOVA, $P=0.068$ ). This suggests that eels with faster somatic growth have smaller otoliths. This regression provided the coefficients for the SPH back-calculation model used to estimate lengths at ages for eels that underwent $\mathrm{Sr}: \mathrm{Ca}$ analysis.

\section{Difference in growth rate among habitat use patterns}

The mean $( \pm \mathrm{SD})$ annual growth rates have been compared among eels with different habitat use strategies (i.e., resident eels vs. inter-habitat shifter eels; Table 2 and Fig. 6). In the TR, resident FW eels showed similar annual growth values (mean \pm $\mathrm{SD}=5.7 \pm 2.4 \mathrm{~cm} \cdot \mathrm{year}^{-1}$ ) with respect to the HIS $\left(6.1 \pm 4.1 \mathrm{~cm} \cdot\right.$ year $^{-1} ; t$-test $\left.P=0.650\right)$. On the other hand, mean growth rate of LL eels resident in BW $\left(8.1 \pm 4.2 \mathrm{~cm} \cdot\right.$ year $\left.^{-1}\right)$ was significantly higher than the one observed for LL shifter eels $\left(6.4 \pm 3.1 \mathrm{~cm} \cdot\right.$ year $^{-1} ; t$-test, $\left.P<0.05\right)$. In contrast, in $\mathrm{CL}$, the growth rate comparison shows a higher

Table 2. Mean annual growth $\left(\mathrm{cm} \cdot \mathrm{year}^{-1}\right)$ of European eels with different habitat use strategies estimated from otolith radius back-calculation and pairwise statistical analysis (one-way Anova and permutation $t$-test).

\begin{tabular}{|c|c|c|c|c|c|c|}
\hline & \multicolumn{2}{|c|}{ Tiber River } & \multicolumn{2}{|c|}{ Lesina lagoon } & \multicolumn{2}{|c|}{ Caprolace lagoon } \\
\hline & $R_{\mathrm{FW}}$ & $\mathrm{HIS}_{\mathrm{BW}-\mathrm{FW}}$ & $R_{\mathrm{BW}}$ & $\mathrm{HIS}_{\mathrm{BW}-\mathrm{SW}}$ & $R_{\mathrm{BW}-\mathrm{SW}}$ & $\mathrm{HIS}_{\mathrm{BW}-\mathrm{SW}}$ \\
\hline Mean $\left(\mathrm{cm} \cdot \mathrm{year}^{-1}\right)$ & 5.66 & 6.10 & 8.13 & 6.37 & 4.46 & 5.57 \\
\hline $\mathrm{SD}\left(\mathrm{cm} \cdot \mathrm{year}^{-1}\right)$ & 2.42 & 4.09 & 4.16 & 3.07 & 1.95 & 2.16 \\
\hline No of eels & 9 & 6 & 13 & 7 & 18 & 3 \\
\hline $\begin{array}{l}\text { No of annual } \\
\text { increments }\end{array}$ & 42 & 39 & 69 & 47 & 156 & 18 \\
\hline anova $F$-value & 2.86 & & 1.83 & & 1.23 & \\
\hline Anova $P$-value & 0.56 & & $<0.05$ & & $<0.05$ & \\
\hline Perm. $t$-test $P$-value & 0.57 & & $<0.05$ & & $<0.05$ & \\
\hline
\end{tabular}

HIS, habitat inter-shifter. 


\section{Capoccioni et al.}

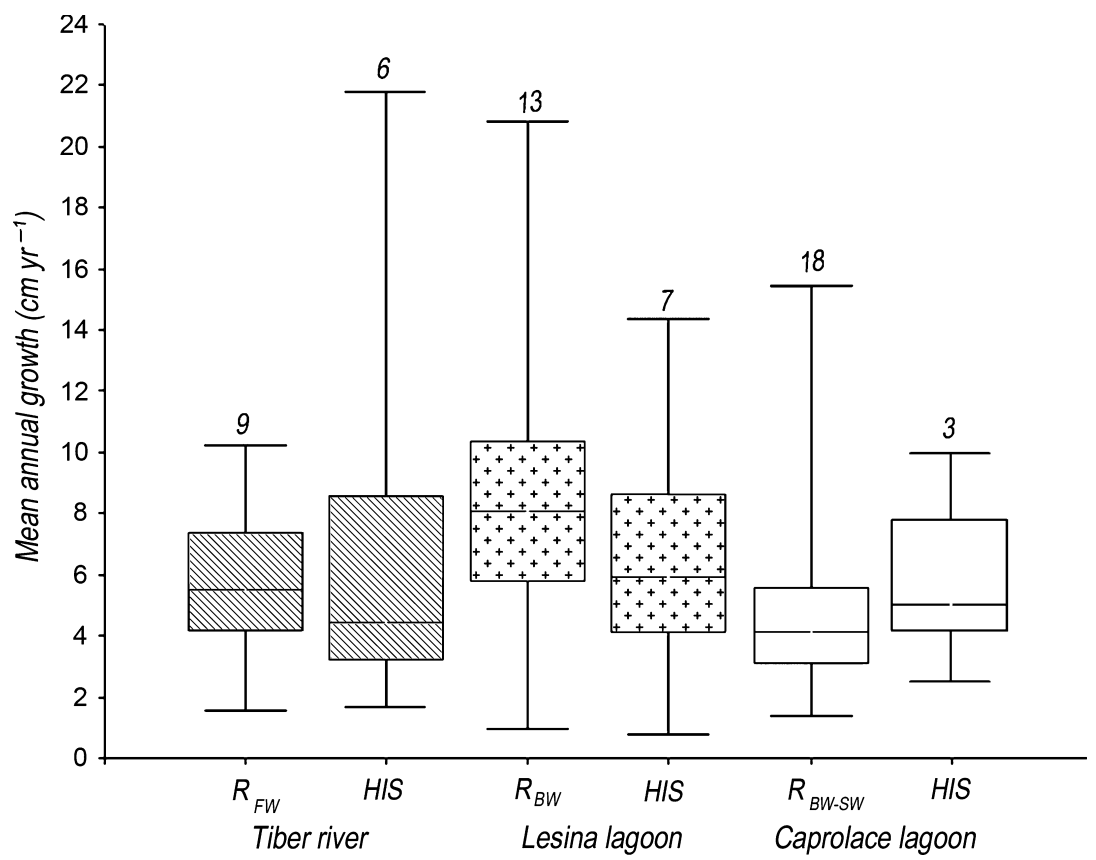

Fig. 6. Differences in eel growth rates displaying different habitat use strategies: resident eels $(R)$ and eels that shifted among different habitats (HIS).

value of the annual growth rate in $\mathrm{HIS}_{\mathrm{BW}-\mathrm{FW}}$ eels with respect to the value of the $R_{\mathrm{BW}-\mathrm{SW}}$ (respectively $5.6 \pm 2.2$ and $4.5 \pm 2.0 \mathrm{~cm} \cdot$ year $^{-1}$; $t$-test, $P<0.05$ ).

\section{Discussion}

Biological significance of the transitional environments

Anguillid eels are catadromous fishes because they spawn in the ocean and juveniles and subadults grow in FW habitats. However, it has been shown, on the basis of analysis of otolith Sr:Ca ratios conducted in recent years, that all eel species do not fall strictly into this category because their life cycle has a certain variability. Many studies revealed that among a single eel stock, different life-history tactics coexist, which are related to a choice of habitat (marine, brackish and fresh water) or a shift among habitats (Tsukamoto \& Arai 2001; Jessop et al. 2002; Tzeng et al. 2002, 2003; Morrison et al. 2003; Kotake et al. 2004). Because of these facultative movements between salinity zones, the habitat where an eel has been sampled does not reliably indicate where previous growth has occurred. Proposed explanations for facultative migration between habitats of different salinities were the relative availability of food (Gross 1987), looking for a faster growth environment, avoidance of competition, agonistic interactions and cannibalism (Daverat et al. 2006; Shiao et al. 2006; Edeline et al. 2007). However, in evolutionary terms, the existence of different migratory patterns in diadromous fishes, including anguillid eels, can be viewed as a mechanism that promotes population resiliency by hedging against unforeseen adverse circumstances in any habitat (Secor \& Rooker 2005).

Transitional waters have always been acknowledged as important environments for many fish species because they represent suitable colonisation habitats for both marine and FW species. On the other hand, the extreme variability of these habitats influences the occurrence and distribution of fishes differently. Transitional habitats in the Mediterranean area, such as lagoons and estuaries, are characterised by abiotic and biotic forces completely different from those involved in Atlantic and North European coastal environments. On the other hand, within each geographical range and latitude, an extreme variability is the rule, and no two coastal lagoons or two estuaries are identical in terms of both biotic and abiotic (including morphology, hydrology, climate, local boundary conditions) characteristics.

\section{Habitat use in Mediterranean region}

Our results highlight differences in habitat use, as well as in biological characteristics, of three Mediterranean local stocks situated at the same latitude. The otolith $\mathrm{Sr}: \mathrm{Ca}$ ratio analysis shows that eels in TW such as coastal lagoons and estuaries display remarkable flexibility in habitat use (i.e., from FW riverine to brackish and SW sectors in lagoons), as shown by the several migratory patterns that have been observed: FW, SW and BW residents and interhabitat shifter eels (Figs 3-5). The fraction of eels adopting a resident habit varies between the three 
environments: $60 \%$ in the River Tiber, $65 \%$ in Lesina lagoon and $85.7 \%$ in CL. These results contrast with those of other studies where residency in estuaries and coastal sites is a less common life-history trait than nomadic movements between water masses of different salinity (Daverat et al. 2006). In accordance with this author, Laffaille et al. (2005) and Panfili et al. (2012) found that European eels may preferably adopt a sedentary lifestyle preferentially in FW habitats. Our results in contrast highlight that in coastal lagoons in the Mediterranean area as well as in estuaries, residency, irrespective of salinity, is the prevailing habit, and nomadic behaviour is less frequent.

\section{Possible explanations of nomadic behaviour}

Habitat inter-shifter eels in the TR, which showed an experience in $\mathrm{BW}$ (35\%), probably moved in zones where the saline wedge is permanent during the whole year (approximately $10 \mathrm{~km}$ far the sampling site in the direction of the river mouth). As no differences in growth rate were found between HIS and resident FW eels from the TR, the main cause for the choice of migratory behaviour could be accidental. The ecological characteristics and consequently the productivity and food availability of the BW zone (all along the saline wedge range of the estuary) are quite similar to those of adjacent zones with salinity close to 0 . In this river, the final stretch is approximately $50 \mathrm{~km}$ long because it is barred by the Castel Giubileo Dam, which hampers eel colonisation in the upper stretches of the river. It could be hypothesised that most eels remain in FW habitats with a limited home range (Laffaille et al. 2005; Tabouret et al. 2010), while others move between different salinity zones that are only few $\mathrm{km}$ from each other when searching for food.

The LL is a wider and complex water body $(20 \mathrm{~km}$ long and $3 \mathrm{~km}$ wide) typically characterised by both FW and SW inputs that shape a stable spatial pattern on the eastern-western axis of the basin. Here, shifter eels, experiencing both SW and BW, probably move between the central area of the lagoon and sectors near the tidal channel where salinity levels are higher over the whole year. In LL, eels with a resident behaviour $\left(R_{\mathrm{BW}}\right)$ show faster growth compared with HIS. Because Lesina is considered an hypertrophic lagoon (Manzo 2010), as reflected also by eels mean annual growth increments $\left(8.5 \pm 2.9 \mathrm{~cm} \cdot \mathrm{year}^{-1}\right)$, the significant slower growth of individuals moving between different salinity zones could be due to the years spent in SW zones where food availability is lower in comparison with the BW zones close to the FW inputs. Moreover, as LL is a very wide lagoon, the cost of migration involved during shifts could have played an important role.
In CL, a relatively small environment $(3.7 \mathrm{~km}$ length and $0.8 \mathrm{~km}$ large), only $14.3 \%$ of eels ( $\mathrm{HIS}_{\mathrm{BW}-\mathrm{SW}}$ ) experienced a residence in $\mathrm{BW}$ for more than 1 year. Most eels $(85.7 \%)$ yielded a Sr:Ca pattern accounting for shifts between BW and SW with a time frame of these movements being very short (i.e., 6 months), that have been interpreted as salinity fluctuations of the environment rather than as movements of the fish. The absence of FW inlets and the small size of the lagoon probably account for an alternative hypothesis that these eels might also be resident in the lagoon and that the $\mathrm{Sr}: \mathrm{Ca}$ ratio pattern observed in their otoliths is due to seasonal variations of salinity in the lagoon.

The interpretation of our results could be affected by confounding factors as temperature and growth rates because several studies had shown that, as well as the water salinity, these parameters could affect the incorporation of trace elements into otolith matrix (Campana 1999). These effects, as well as the origin of the ions deposited in the otolith aragonite, have been seldom investigated. It is supposed that they enter the plasma via intestinal absorption or by the gill epithelium, and from the plasma they pass in the endolymph of the inner ear (Campana 1999). The otolith composition will then depend on the relative contribution of ambient water and diet, as well as the otolith shape (Capoccioni et al. 2011), but it has been acknowledged that water is the primary source of ions in fish otoliths (Milton \& Chenery 2001; Walter $\&$ Thorrold 2006). Temperature is thought to be positively correlated with $\mathrm{Sr}$ :Ca ratio in the otoliths (Elsdon \& Gillanders 2002), but in this study, this factor is probably not relevant because all three study sites display similar temperature regimes over the whole year as well as the same mean annual values (approximately $18{ }^{\circ} \mathrm{C}$ ).

Otolith $\mathrm{Sr}: \mathrm{Ca}$ ratios are negatively correlated with growth rate in many fish species (Sadovy \& Severin 1992) and also in the European eel (Tzeng et al. 2000), but the mechanisms are still not clear (Lin et al. 2007). Accordingly, the general pattern observed in Figs 4 and 5, where Lesina eels display $\mathrm{Sr}$ :Ca ratios lower than those of Caprolace, could correspond to differences in growth rates (LL, $8.5 \mathrm{~cm} \cdot$ year $^{-1}$; CL $4.4 \mathrm{~cm} \cdot$ year $^{-1}$, see Table 1). Therefore, Morrison et al. (2003) and Thibault et al. (2007) suggested that the growth rate observed in anguillid eels was a consequence rather than a cause of variable migratory patterns.

\section{Advantages and cost of inter-habitat movements}

These results support the hypothesis that habitat selection of eel during the growth phase may be opportunistic, not obligatory. Because choice of the 


\section{Capoccioni et al.}

growth habitat may depend on the food availability and carrying capacity of the habitat, the migration choice could be explained in relation to the balance between the advantages obtained from migration and the costs involved. Advantages include such aspects as increased food supply, avoidance of potentially harmful environmental conditions and/or a movement to more favourable ones and the availability of more living space. Costs of migration include mortalities resulting from migration itself as well as changed environmental conditions that may be intolerable, specifically osmoregulatory stress in euryhaline species (McDowall 1988; Tzeng et al. 2003). In diadromous species, such as A. anguilla, facultative movements between zones at different salinity may occur when the gain in fitness from using a second habitat minus the migration costs of moving between habitats exceeds the fitness of remaining in a single habitat (Gross 1987). Specific patterns of movements and habitat use are probably triggered by biotic and abiotic factors associated with local habitats, particularly productivity gradients.

The present study confirms the phenotypic plasticity hypothesis of habitat use of the eel. Because European eel is assumed to be a panmictic population, and this is confirmed also for local stocks in the Mediterranean area (Pujolar et al. 2009a,b) and as this precludes segregation of genotypes, local differences in life-history patterns are likely to be of phenotypic origin (Jessop et al. 2004). The present findings confirm in fact that in TW in this region, growth rates and habitat use show typical patterns that are different from those observed in rivers and coastal habitats at more northern latitudes. The prevailing habitat use behaviour in Mediterranean TWs is the residency, while nomadic behaviour is less frequent. Moreover, with respect to Northern European environments, these productive ecosystems provide a more favourable condition for growth, that is, higher growth rates (Melià et al. 2006; Yalçõn-Özdilek et al. 2006; Bevacqua et al. 2012), because phenotypic growth is positively correlated with latitude and temperature (Vøllestad 1992). Once again, the knowledge of how fish use their habitat in space and time throughout their life history appears to be fundamental for the understanding of the ecology and population dynamics, and to determine habitats functions, also to allow for the development of effective conservation measures (Gillanders 2002).

\section{Acknowledgements}

This work was supported by the Italian Ministero per le Politiche Agricole, Alimentari e Forestali, grant 'MIPAF Anguilla 2012 ' to EC. The Authors are grateful to an anonymous reviewer for their useful comments that allowed to improve the manuscript.

\section{References}

Acou, A., Lefebvre, F., Contournet, P., Poizat, G., Panfili, J. \& Crivelli, A.J. 2003. Silvering of female eels (Anguilla anguilla) in two sub-populations of the Rhône delta. Bulletin Francais de la Peche et de la Pisciculture 368: 55-68.

Alonghi, D.M. 1998. Coastal ecosystem processes. Boca Raton, FL: CRC Press. 188 pp.

Arai, T., Kotake, A. \& McCarthy, T.K. 2006. Habitat use by the European eel Anguilla anguilla in Irish waters. Estuarine, Coastal and Shelf Science 67: 569-578.

Bevacqua, D., Capoccioni, F., Melià, P., Vincenzi, S., Pujolar, J.M., De Leo, G.A. \& Ciccotti, E. 2012. Fishery-induced selection for slow somatic growth in European Eel. PLoS ONE 7: e37622.

Brown, R.J. \& Severin, K.P. 2009. Otolith chemistry analyses indicate that water $\mathrm{Sr}: \mathrm{Ca}$ is the primary factor influencing otolith $\mathrm{Sr}: \mathrm{Ca}$ for freshwater and diadromous fish but not for marine fish. Canadian Journal of Fisheries and Aquatic Sciences 66: 1790-1808.

Campana, S. 1999. Chemistry and composition of fish otoliths: pathways, mechanisms and applications. Marine Ecology Progress Series 188: 263-297.

Capoccioni, F., Costa, C., Aguzzi, J., Menesatti, P., Lombarte, A. \& Ciccotti, E. 2011. Ontogenetic and environmental effects on otolith shape variability in three Mediterranean European eel (Anguilla anguilla, L.) populations. Journal of Experimental Marine Biology and Ecology 397: 1-7.

Carrada, G.C. \& Fresi, E. 1988. Le lagune salmastre. Alcune riflessioni sui problemi e sui metodi. In: Carrada, G.C., Cicogna, F., Fresi, E., eds. Le lagune costiere: ricerca e gestione. Massa Lubrense, Napoli: Clem, pp. 35-55.

Colombo, G. \& Grandi, G. 1996. Histological study of the development and sex differentiation of the gonad in the European eel. Journal of Fish Biology 48: 493-512.

Daverat, F. \& Tomás, J. 2006. Tactics and demographic attributes in the European eel Anguilla anguilla in the Gironde watershed, SW France. Marine Ecology Progress Series 307: 247-257.

Daverat, F., Limburg, K., Thibault, I., Shiao, J.-C., Dodson, J.J., Caron, F., Tzeng, W.-N., Iizuka, Y. \& Wickstrom, H. 2006. Phenotypic plasticity of habitat use by three temperate eel species, Anguilla anguilla, A. japonica and A. rostrata. Marine Ecology Progress Series 308: 231-241.

Edeline, E., Beaulaton, L., Le Barh, R. \& Elie, P. 2007. Dispersal in metamorphosing juvenile eel Anguilla anguilla. Marine Ecology Progress Series 344: 213-218.

Elsdon, T.S. \& Gillanders, B.M. 2002. Interactive effects of temperature and salinity on otolith chemistry: challenges for determining environmental histories of fish. Canadian Journal of Fisheries and Aquatic Sciences 59: 1796-1808.

Elsdon, T.S., Wells, B.K., Campana, S.E., Gillanders, B.M., Jones, C.M., Limburg, K.E., Secor, D.H., Thorrold, S.R. \& Walther, B.D. 2008. Otolith chemistry to describe movements and life-history parameters of fishes: hypotheses, assumptions, limitations and inferences. Oceanography and Marine Biology: An Annual Review 46: 297-330. 
Francis, R.I.C.C. 1990. Back-calculation of fish length: a critical review. Journal of Fish Biology 36: 883-902.

Francis, R.I.C.C. 1995. The problem of specifying otolithmass growth parameters in the radiometric estimation of fish age using whole otoliths. Marine Biology 124: 169-176.

Franco, A., Franzoi, P., Malavasi, S., Riccato, F., Torricelli, P. \& Mainardi, D. 2006. Use of shallow water habitats by fish assemblages in a Mediterranean coastal lagoon. Estuarine Coastal and Shelf Science 66: 67-83.

Gillanders, B.M. 2002. Connectivity between juvenile and adult fish populations: do adults remain near their recruitment estuaries? Marine Ecology Progress Series 240: 215223.

Gross, M.R. 1987. Evolution of diadromy in fishes. American Fisheries Society Symposium 1: 14-25.

Hilmer, T. \& Bate, G.C. 1991. Vertical migration of a flagellate-dominated bloom in a shallow South African estuary. Botanica Marina 34: 113-121.

ICES. 2006. Report of the 2006 session of the joint EIFAC/ ICES working group on eels. Rome, 23-27 January 2006, EIFAC Occasional Paper No. 38, ICES CM, ACFM:16, 367 pp.

ICES. 2009. Annex 4: manual for the ageing of Atlantic eel. In ICES Workshop on Age Reading of European and American Eel (WKAREA), 20-24 April 2009, Bordeaux, France. ICES CM 438 2009:ACOM 48.

Istituto Idrografico di Roma. 2010. Bollettini della qualità dell'acqua alla stazione di Porta Portese.

Jessop, B.M., Shiao, J.C., Iizuka, Y. \& Tzeng, W.-N. 2002. Migratory behaviour and habitat use by American eels Anguilla rostrata as revealed by otolith microchemistry. Marine Ecology Progress Series 233: 217-229.

Jessop, B., Shiao, J., Iizuka, Y. \& Tzeng, W.-N. 2004. Variation in the annual growth, by sex and migration history, of silver American eels Anguilla rostrata. Marine Ecology Progress Series 272: 231-244.

Kapetsky, J.M. \& Lasserre, G. 1984. Management of coastal lagoon fisheries. Studies Review GFCM 61: 439-776.

Kawakami, Y., Mochioka, N., Morishita, K., Tajima, T., Nakagawa, H., Toh, H. \& Nakazono, A. 1998. Factors influencing otolith strontium/calcium ratios in Anguilla japonica elvers. Environmental Biology of Fishes 52: 299-303.

Kotake, A., Arai, T., Ohji, M., Yamane, S., Miyazaki, N. \& Tsukamoto, K. 2004. Application of otolith microchemistry to estimate the migratory history of Japanese eel Anguilla japonica on the Sanriku Coast of Japan. Journal of Applied Ichthyology 20: 150-153.

Kraus, R.T. \& Secor, D.H. 2004. Incorporation of strontium into otoliths of an estuarine fish. Journal of Experimental Marine Biology and Ecology 302: 85-106.

Laffaille, P., Acou, A. \& Guillouet, J. 2005. The yellow European eel (Anguilla anguilla L.) may adopt a sedentary lifestyle in inland freshwaters. Ecology of Freshwater Fish 14: 191-196.

Lin, Y.-J., Ložys, L., Shiao, J., Iizuka, Y. \& Tzeng, W.-N. 2007. Growth differences between naturally recruited and stocked European eel Anguilla anguilla from different habitats in Lithuania. Journal of Fish Biology 71: 1773-1787.

Lin, Y.-J., Shiao, J.-C., Ložys, L., Plikšs, M., Minde, A., Iizuka, Y., Rašals, I. \& Tzeng, W.-N. 2009. Do otolith annular structures correspond to the first freshwater entry for yel- low European eels Anguilla anguilla in the Baltic countries? Journal of Fish Biology 75: 2709-2722.

Manzo, C. 2010. Fish assemblages in three Mediterranean coastal lagoons: structure, functioning and spatio-temporal dynamics. PhD thesis. University of Tor Vergata: Rome, 105 pp. Available at: http://hdl.handle.net/2108/1274.

McDowall, R.M. 1988. Diadromy in fishes: migrations between freshwater and marine environments. Portland, OR, USA: Timber Press. 308 pp.

Melià, P., Bevacqua, D., Crivelli, A.J., De Leo, G.A., Panfili, J. \& Gatto, M. 2006. Age and growth of Anguilla anguilla in the Camargue lagoons. Journal of Fish Biology 68: 876-890.

Milton, D.A. \& Chenery, S.P. 2001. Sources and uptake of trace metals in otoliths of juvenile barramundi (Lates calcarifer). Journal of Experimental Marine Biology and Ecology 264: 47-65.

Morrison, W.E., Secor, D.H. \& Piccoli, P.M. 2003. Estuarine habitat use by Hudson river American eels as determined by otolith strontium:calcium ratios. In: Dixon, D.A., ed. Biology, management and protection of catadromous eels. American Fisheries Society Symposium 33: 87-100.

Nonnis Marzano, C., Scalera, C., Liaci, L., Fianchini, A., Gravina, F., Mercurio, M. \& Corriero, G. 2003. Distribution, persistence and change in the macrobenthos of the lagoon of Lesina (Apulia, southern Adriatic Sea). Acta Adriatica 26: 57-66.

Odum, E.P. 1969. The strategy of ecosystem development. Science 164: 262-270.

Odum, E.P. 1985. Trends expected in stressed ecosystems. Bioscience 35: 419-422.

Panfili, J., Darnaude, A.M., Lin, Y.J., Chevalley, M., Iizuka, Y., Tzeng, W.-N. \& Crivelli, A.J. 2012. Habitat residence during continental life of the European eel Anguilla anguilla investigated using linear discriminant analysis applied to otolith Sr:Ca ratios. Aquatic Biology 15: 175-185.

Patrolecco, L., Ademollo, N., Capri, S., Pagnotta, R. \& Polesello, S. 2010. Occurrence of priority hazardous PAHs in water, suspended particulate matter, sediment and common eels (Anguilla anguilla) in the urban stretch of the River Tiber (Italy). Chemosphere 81: 1386-1392.

Pérez-Ruzafa, A., Monpeán, M.C. \& Marcos, C. 2007. Hydrographic, geomorphologic and fish assemblage relationships in coastal lagoons. Hydrobiologia 577: 107-125.

Pérez-Ruzafa, A., Concepción, M., Pérez-Ruzafa, I.M. \& Pérez-Marcos, M. 2011. Coastal lagoons: "Transitional ecosystems" between transitional and coastal waters. Journal of Coastal Conservation 15: 369-392.

Prato, S., Morgana, J., Lavalle, P., Finoia, M., Lattanzi, L., Nicoletti, L., Ardizzone, G. \& Izzo, G. 2009. Application of biotic and taxonomic distinctness indices in assessing the Ecological Quality Status of two coastal lakes: Caprolace and Fogliano lakes (Central Italy). Ecological Indicators 9: 568-583.

Pujolar, J.M., De Leo, G.A., Ciccotti, E. \& Zane, L. 2009a. Genetic composition of Atlantic and Mediterranean recruits of European eel Anguilla anguilla based on EST-linked microsatellite loci. Journal of Fish Biology 74: 2034-2046.

Pujolar, J.M., Bevacqua, D., Capoccioni, F., Ciccotti, E., De Leo, G.A. \& Zane, L. 2009b. Genetic variability is unrelated to growth and parasite infestation in natural populations of the European eel (Anguilla anguilla). Molecular Ecology 18: 4604-4616. 


\section{Capoccioni et al.}

Roselli, L., Fabbrocini, A., Manzo, C. \& D'Adamo, R. 2009. Hydrological heterogeneity, nutrient dynamics and water quality of a non-tidal lentic ecosystem (Lesina Lagoon, Italy). Estuarine Coastal and Shelf Science 84: 539-552.

Sadovy, Y. \& Severin, K.P. 1992. Trace elements in biogenic aragonite: correlation of body growth rate and strontium levels in the otoliths of the white grunt, Haemulon plumieri (Pisces: Haemulidae). Bulletin of Marine Science 50: 237257.

Secor, D.H. \& Rooker, J.R. 2000. Is otolith strontium a useful scalar of life cycles in estuarine fishes? Fisheries Research 46: 359-371.

Secor, D.H. \& Rooker, J.R. 2005. Connectivity in the life histories of fishes that use estuaries. Estuarine Coastal and Shelf Science 64: 1-3.

Shiao, J.C., Ložys, L., Iizuka, Y. \& Tzeng, W.-N. 2006. Migratory patterns and contribution of stocking to the population of European eel in Lithuanian waters as indicated by otolith Sr:Ca ratios. Journal of Fish Biology 69: 749-769.

Tabouret, H., Bareille, G., Claverie, F., Pècheyran, C., Prouzet, P. \& Donard, O.F.X. 2010. Simultaneous use of strontium:calcium and barium:calcium ratios in otoliths as markers of habitat: application to the European eel (Anguilla anguilla) in the Adour basin, South West France. Marine Environmental Research 70: 35-45.

Tett, P., Gilpin, L., Svendsen, H., Erlandsson, P., Larsson, U., Kratzer, S., Fouilland, E., Janzen, C., Lee, J.Y., Grenz, C., Newton, A., Ferreira, J.G., Fernandes, T. \& Scory, S. 2003. Eutrophication and some European waters of restricted exchange. Continental Shelf Research 23: 1635-1671.

Thibault, I., Dodson, J.J., Caron, F., Tzeng, W.N., Iizuka, Y. \& Shiao, J. 2007. Facultative catadromy in American eels: testing the conditional strategy hypothesis. Marine Ecology Progress Series 344: 219-229.

Thorrold, S.R., Campana, S.E., Jones, C.M. \& Swart, P.K. 1997. Factors determining $\delta^{13} \mathrm{C}$ and $\delta^{18} \mathrm{O}$ fractionation in aragonitic otoliths of marine fish. Geochimica et Cosmochimica Acta 61: 2909-2919.

Tsukamoto, K. \& Arai, T. 2001. Facultative catadromy of the eel Anguilla japonica between freshwater and seawater habitats. Marine Ecology Progress Series 220: 265-276.
Tsukamoto, K., Nakai, I. \& Tesch, F.W. 1998. Do all freshwater eels migrate? Nature 396: 635-636.

Tzeng, W.-N., Severn, K.P. \& Wickstrom, H. 1997. Use of otolith microchemistry to investigate the environmental history of European eel Anguilla anguilla. Marine Ecology Progress Series 149: 73-81.

Tzeng, W.-N., Wang, C.H., Wickstrom, H. \& Reizenstein, M. 2000. Occurrence of the semi-catadromous European eel Anguilla anguilla (L.) in Baltic Sea. Marine Biology 137: 93-98.

Tzeng, W.-N., Shiao, J.C. \& Iizuka, Y. 2002. The use of otolith $\mathrm{Sr}: \mathrm{Ca}$ ratios to study the riverine migratory behaviours of Japan- ese eel Anguilla japonica. Marine Ecology Progress Series 245: 213-221.

Tzeng, W.-N., Iizuka, Y., Shiao, J., Yamada, Y. \& Oka, H.P. 2003. Identification and growth rates comparison of divergent migratory contingents of Japanese eel (Anguilla japonica). Aquaculture 216: 77-86.

Vøllestad, L.A. 1992. Geographic variation in age and length at metamorphosis of maturing European eel: environmental effects and phenotypic plasticity. Journal of Animal Ecology 61: 41-48.

Walther, B.D. \& Thorrold, S.R. 2006. Water, not food, contributes the majority of strontium and barium deposited in the otoliths of a marine fish. Marine Ecology Progress Series 311: $125-130$.

Whitfield, A.K. \& Wooldridge, T.H. 1994. Changes in freshwater supplies to southern African estuaries: some theoretical and practical considerations. In: Dyer, K.R., Orth, R.J., eds. Changes in fluxes in estuaries: implications from science to management. Fredensborg: Olsen and Olsen, pp. 41-50.

Yalçõn-Özdilek, S., Gumus, A. \& Dekker, W. 2006. Growth of European Eel in a Turkish River at the South-Eastern limit of its distribution. Electronic Journal of Ichthyology 2: 55-64.

Zimmerman, C.E. 2005. Relationship of otolith strontium-tocalcium ratios and salinity: experimental validation for juvenile salmonids. Canadian Journal of Fisheries and Aquatic Sciences 62: 88-97. 